\title{
Value of tomography in detecting breast masses and discriminating malign and benign lesions
}

\author{
Hatice Ayça Ata Korkmaz (ID), Miraç İsmet Çakır ${ }^{1}$ (ID), Eser Bulut ${ }^{1}$ (ID), Sibel Kul²(iD) \\ 1 Department of Radiology, University of Health Sciences, Kanuni Training and Research Hospital, Trabzon, Turkey \\ 2 Department of Radiology, Karadeniz Technical University School of Medicine, Trabzon, Turkey
}

\section{ABSTRACT}

Objective: The main purpose of the present study was to determine the effectivity of computerized tomography (CT) in detecting breast masses and discriminating masses as malignant or benign.

Material and Methods: After having received the institutional local ethics committee approval, an experienced radiologist who did not participate in the study created a patient pool by searching our health center's Pathology department database between 2010 and 2018. The group created consisted of dense and non-dense breast types equally and included approximately similar percentages of benign and malignant breast mass sizes. Finally, 70 subjects were included: 30 females with definite malign, 20 with definite benign breast masses, and 20 without any breast pathology based on mammography and ultrasonography results, who were considered as the control group. Three experienced Radiologists (R1, R2, R3) who were not aware of the final diagnosis evaluated all images independently. Radiologist performance was assessed by calculating the area under the receiver operating characteristic curve (AUC) and interobserver reliability values were estimated by intraclass correlation coefficient (ICC) analysis.

Results: The diagnostic accuracy suitability of CT according to BI-RADS scores for R1, R2 and R3 were found as $p<0.001, p<0.001$ and $p<0.001$, respectively. There were significant interobserver reliability rates between all investigators $(p=0.0001)$.

Conclusion: CT may be used as a valuable diagnostic tool in discriminating breast masses with further training in widely varying appearances of normal breast tissues leading to false positive findings.

Keywords: Computerized tomography, thorax, breast cancer, breast tomography

Cite this article as: Ata Korkmaz HA, Çakır Mi, Bulut E, Kul S. Value of tomography in detecting breast masses and discriminating malign and benign lesions. Turk J Surg 2019; 35 (4): 265-272

Corresponding Author Hatice Ayça Ata Korkmaz

E-mail: dr.h.aycaatakorkmaz@gmail.com

Received: 28.06 .2018

Accepted: 05.11.2018

Available Online Date: 04.05.2019

(c) Copyright 2019 by Turkish Surgical Society Available online at www.turkjsurg.com

DOI: $10.5578 /$ turkjsurg.4258

\section{INTRODUCTION}

Breast cancer, which is the most commonly seen cancer type in women, is the second most important leading cause of cancer deaths in women. Majority of breast cancer detection is made by breast cancer screening programs in routine clinical examinations or during body image screening for other disorders. Mammography, sonography and magnetic resonance imaging (MRI) are standard imaging modalities used to evaluate breast cancer worldwide (1). However, computerized tomography (CT) may occasionally be the first imaging modality to reveal a new primary breast cancer (2).

Over the past 10 years, the use of cross-sectional imaging has increased signifcantly.

A recent study has shown a stunning 226\% increase in thoracic CT assessment in emergency departments (3).

Even thoracic $\mathrm{CT}$ is used to performed for evaluating lung, mediastinum, pleura, diaphragm and chest wall pathologies, breast tissue is usually contained in the area of thoracal CT sections.

$\mathrm{CT}$ is mainly valuable to determine breast masses with dense breast pattern in women $(4,5)$. However, for lesions that are close to the chest wall or masses located in the axillary regions, CT may be superior to other imaging modalities.

There are studies about incidentally detected breast lesions by tomography $(2,6-15)$. 
$\mathrm{CT}$ imaging features of breast cancer have been investigated in some studies $(16,17)$.

The purpose of present study was to determine the effectivity of $\mathrm{CT}$ in detecting breast masses and discriminating malign and benign masses.

To the best of our knowledge, there is no reader study investigating the diagnostic value of thoracic CT in detecting breast cancer and its role in discriminating malign and benign lesions.

In this context, our study is the first in the current literature.

\section{MATERIAL and METHODS}

\section{Study Population}

After having received institutional local ethics committee approval (2017/61), an experienced radiologist, who had no knowledge of clinical data and did not participate in the reader study, created a patient pool among 1000 patients by searching our health center's Pathology department database between 2010 and 2018. All of the selected patients were correlated with our radiology breast department database, and results of the breast sonography and mammography examinations before sonographically guided core needle biopsy and/or surgery was collected.

Patients without available CT images within one month after mammographic and sonographic examination were excluded from the study.

Gold standard in this study was determined as histopathologic data for suspected malignant lesions or radiological stability for the lesions in the follow-up examinations for at least 24 months (18).

The researcher ensured that the breast types were equally present in the selected patient pool.

While forming the benign and malignant breast mass groups, the researcher was careful that the mass sizes in both groups were close to each other. Lesion measurements and breast density classifications (18) were determined by the same researcher.

Thirty female patients with histopathologically definitive malignant breast masses confirmed by thoracic CT and 20 benign breast masses, whose definitive diagnosis was made histopathologically in ten cases and whose lesion stability was confirmed at a period of 2-year-follow-up in ten cases, were selected.

In total, seventy cases were included into the study, of whom 30 female patients had definitive malignant, 20 had definitive benign breast masses, and the rest of the 20 female patients without any breast pathology according to breast screening programs were included as the control group.

The created pool was evaluated by three experienced radiologists (R1, R2, R3) independently, one of whom was a specialist who had worked on breast for over 18 years (R1). One of the other researchers had twelve years (R2) and the other had eight years (R3) experience in thoracic radiology.

The reviewers were not informed whether there was a lesion or not and of the patients' final diagnoses and mass locations, but were only aware that they had to evaluate the breasts meticulously. The accuracy of the localization of the masses identified during blind evaluation was confirmed subsequently by ultrasound and mammography. Focuses and non-mass lesions were excluded from the study.

This retrospective, single-institution reader study was conducted in compliance with the Helsinki Declaration and good clinical practice guidelines of the Ministry of Health of our country. Secondary to retrospective nature of the study, written informed consent was not acquired.

\section{CT Technique}

Thoracic CT was performed using a 64-detector Multidetector Computerized Tomography (MDCT scanner (Aquilion 64; Toshiba Medical Systems, Otawara, Tochigi, Japan) in supine position. Contrast-enhanced scans were performed. Standard protocol at our hospital is a pitch of 0.828, 0.5 s scanner rotation, $120 \mathrm{kV}, 150$ $\mathrm{mAs}, 38 \mathrm{~cm}$ field of view and $1 \mathrm{~mm}$ slice thickness. Subsequently, a contrast-enhanced helical CT was performed with intravenous administration of non-ionic contrast material (Ultravist; Iopromide, Bayer Health Care Pharmaceuticals, Berlin, Germany), 300 $\mathrm{mg} / \mathrm{mL}$, which was injected as $2 \mathrm{~mL} / \mathrm{kg}$ dose at a speed of 4-6 $\mathrm{mL} / \mathrm{min}$ using an automatic injector system. Scanning was performed 50 seconds after injection of the contrast medium.

\section{CT Image Analysis}

The created CT images, consisting of a total of 70 lesions, were randomly evaluated by the radiologists on a workstation (Leonardo; Siemens Healthcare, Erlangen, Germany) in our radiology department.

All of the reviewers were blinded to each other's findings and decisions.

Evaluation was performed first independently, later in consensus for the presence of masses and for the determination whether these masses were malignant or benign. The accuracy of the localization of the masses identified in blind evaluation was confirmed subsequently by ultrasound and mammography.

CT images were classified into two groups according to whether there were any radiological findings in the breasts within the $\mathrm{CT}$ sections or not.

Lesion visibility was classified into four groups as 0: no, 1: poor, 2: moderate, and 3: high visibility.

The ratio of malignancy suspicion was classified into five main groups as $1 \leq 2 \%, 2=2-10 \%, 3=10-50 \%, 4=50-90 \%, 5 \geq 95 \%$ (Figure 1). 

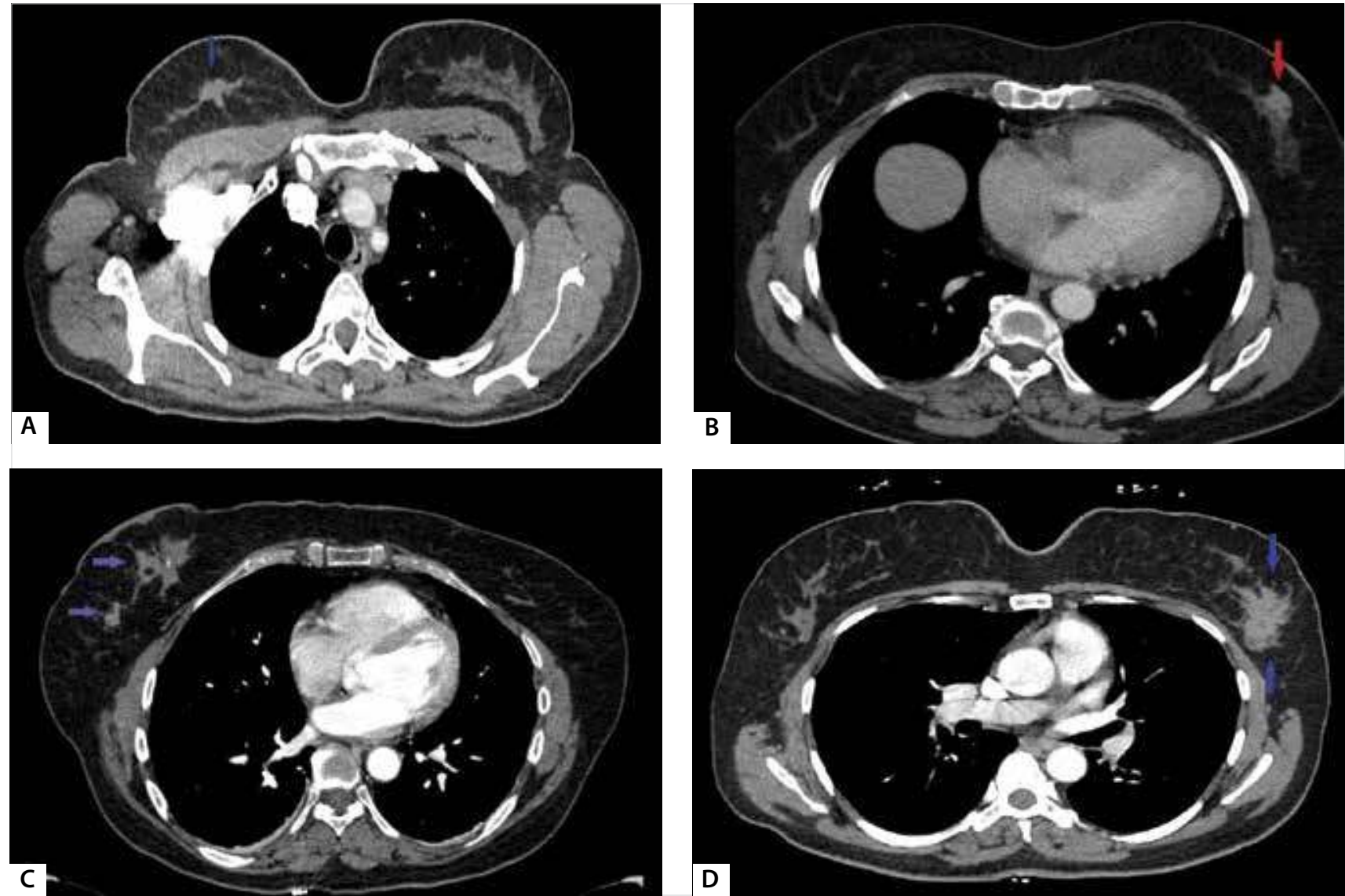

Figure 1. Axial CT image is shown (A) a speculated lesion (blue arrow) with moderate enhancement in the upper middle quadrant of right breast with moderate malignancy suspicion ratio ( $x=10-50 \%$, BI-RADS 3), (B) well defined mass appearance (red arrow) with homogeneous enhancement in the upper middle quadrant of left breast with moderate malignancy suspicion ratio ( $x=50-90 \%$, BI-RADS 4 ), (C) two speculated neighboring lesions (purple arrows) with calcifications in the lower inner quadrant of right breast with high malignancy suspicion ratio ( $x>$ 95\%: BI-RADS 5) and increased skin thickness was also demonstrated in the image, (D) a well-defined, speculated countered mass appearance (blue arrows) with high enhancement pattern in the upper outer quadrant of left breast. This lesion reflects a high-grade malignancy suspicion ratio ( $x>95 \%$ : BI-RADS 5).

Finally, lesions were classified according to the American College of Radiology Classification, Breast Imaging Reporting and Data System $5^{\text {th }}$ edition (BI-RADS) (19).

\section{Statistical Analysis}

Continuous variables were expressed as mean \pm standard deviation (SD) and categorical variables were expressed in percentages.

Sensitivity was calculated as the ratio of true-positive readings among true-positive and false-negative readings. Specificity was calculated as the ratio of true-negative readings among true-negative and false-positive readings.

For evaluating sensitivity and specifity, BI-RADS scores were divided into two groups. BI-RADS 1, 2 and 3 scores were considered as negative findings and BI-RADS 4 a-c and 5 scores were considered as positive findings.
Interobserver correlation coefficient (ICC) was used to determine the degree of compromise on BI-RADS scoring between all observers (20). In this study, an ICC less than 40\% was considered as poor, $40-59 \%$ as fair, $60-74 \%$ as good and $75-100 \%$ as excellent.

For the assessment of diagnostic test accuracy, test sensitivity, specificity and AUC [the area under the receiver-operating characteristic (ROC) curve] were calculated separately for each radiologist.

Discordances in mass visibility were analyzed by using the Wilcoxon matched-pairs signed-ranks test.

For evaluating radiologist performance according to breast density, BI-RADS breast density scores were divided into two groups. BI-RADS 1, 2 scores were determined as not-dense breast and BI-RADS 3 and 4 scores were determined as dense breast types. Radiologist performance was evaluated by calculating the area 
under the receiver operating characteristic curve (AUC) and partial area index above a sensitivity threshold of 0.90 by using malignancy suspect ratings. Significance of the difference between the areas under two Independent ROC curves among all radiologists were calculated by a special statistical analysis program, MedCalc for Windows, version 16.2.1 (MedCalc Software, Ostend, Belgium).

Interobserver reliability values and radiologist agreement for lesion visibility was estimated statistically by ICC analysis.

Statistical analysis was conducted using SPSS 22.0 statistical software (21).

\section{RESULTS}

\section{Characteristics in Subjects}

In order to demonstrate the homogeneity of the created study group, sizes of breast lesions and breast types are shown in Figure 2 .

Mean age was 53 years (range, 32-81 years). Mean lesion size was $2.06 \mathrm{~cm}$ (range, $0.5-4.5 \mathrm{~cm}$ ).

Breast density of the patients according to the BI-RADS classification system and pathologic results of the lesions are summarized in Table 1.

Box plot of each radiologist's visibility scores is shown in Figure 3.

\section{Malignancy Suspicion Ratios}

For R1, R2 and R3, respectively, $p$ values comparing the ratio of malignancy suspect respect to pathology; diagnostic accuracy (AUC) for $C T$ was $p<0.001, p<0.001$ and $p<0.001$.

ROC curve analysis of lesion malignancy suspect ratios is shown in Figure 4.

In the control group without any masses, R1 reported masses in 5 patients (7.15\%) (two of which were malignant); R2 reported

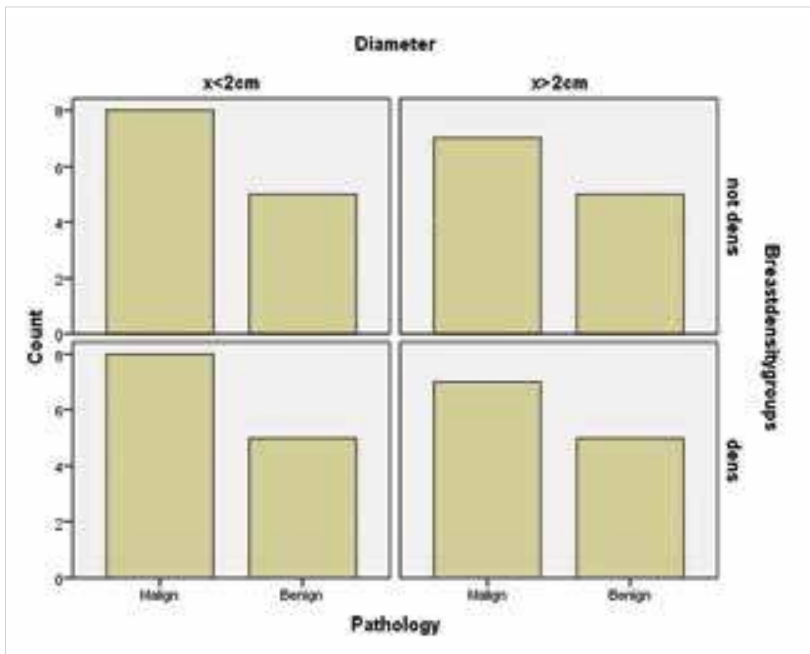

Figure 2. Homogeneity of the study group.
Table 1. Types of breast density according to BI-RADS classification system and pathologic results of the lesions

\begin{tabular}{|l|c|}
\hline Breast density & Number (\%) \\
\hline Not dense & $36(51.4)$ \\
$\quad$ Type 1. Entirely fatty & $8(11.4)$ \\
Type 2. Scattered areas of fibroglandular density & $28(40.0)$ \\
Dense & $34(48.5)$ \\
$\quad$ Type 3. Heterogeneously dense & $29(41.4)$ \\
$\quad$ Type 4. Extremely dense & $5(7.1)$ \\
\hline Pathology & \\
IDC & $25(35.7)$ \\
ILC & $2(2.9)$ \\
DCIS & $1(1.4)$ \\
MIX CA & $1(1.4)$ \\
IPC & $1(1.4)$ \\
Fibrocystic disease & $1(1.4)$ \\
Stable lesion during 24 months & $8(11.4)$ \\
Fibroadenoid hyperplasia & $6(8.6)$ \\
Adenosis & $1(1.4)$ \\
Benign papiller lesions & $1(1.4)$ \\
Minimal epitelial hyperplasia & $1(1.4)$ \\
Non necrotizan granuloma & $1(1.4)$ \\
Lymphoid tissue & $1(1.4)$ \\
Control group & $20(28.6)$ \\
\hline IDC:Ivasive & \\
\hline
\end{tabular}

IDC: Invasive ductal carcinoma; ILC: Invasive lobular carcinoma; DCIS: Ducta carcinoma in situ; MIX CA: Mixed type carcinoma; IPC: Intraductal papillary carcinoma.

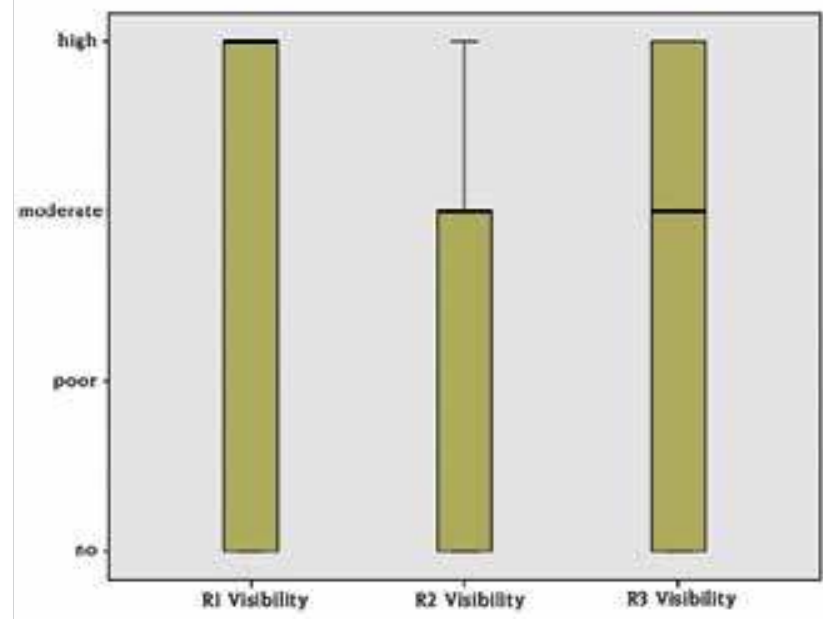

Figure 3. Box plot of the visibility scores of each radiologist.

masses in 7 patients (10\%) (5 of which were malign); and R3 reported masses in 6 patients (8.6\%) (3 of which were malignant). All of these diagnoses were regarded false positive.

Even though patients had benign masses confirmed pathologically, 4 (5.75\%), 13 (18.6\%), and 10 (14.3\%) patients were repor- 


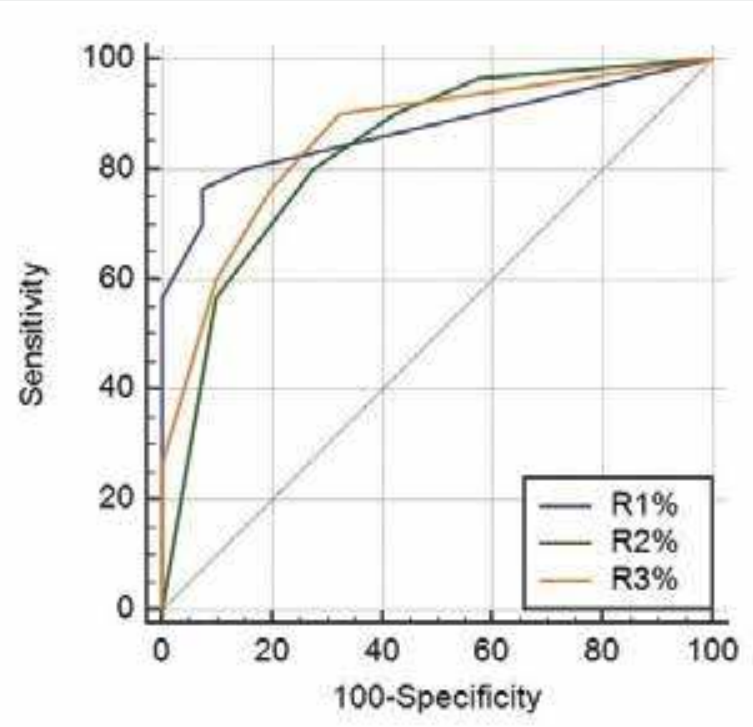

Figure 4. ROC curves of malignancy suspicion ratios with respect to pathology.

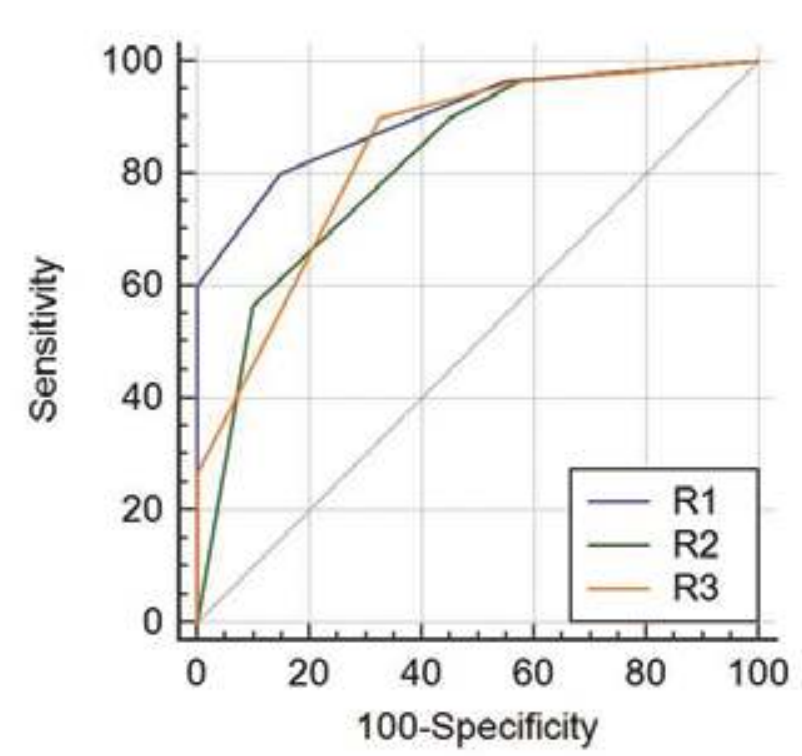

Figure 5. BIRADS ROC curves with respect to pathology.

\begin{tabular}{|c|c|c|c|c|c|c|c|}
\hline \multirow[t]{2}{*}{$\begin{array}{l}\text { Study populition } \\
\text { n (\%) }\end{array}$} & \multicolumn{2}{|l|}{ R1 } & \multicolumn{2}{|l|}{ R2 } & \multicolumn{2}{|l|}{ R3 } & $\begin{array}{c}p \text { value between } \\
R 1, R 2, R 3\end{array}$ \\
\hline & Benign + Normal & Malign & Benign + Normal & Malign & Benign + Normal & Malign & \multirow{3}{*}{0.0001} \\
\hline Malign 30 (42.9) & $6(8.6)$ & $24(34.3)$ & $3(4.3)$ & 27 (38.6) & $3(4.3)$ & $27(38.6)$ & \\
\hline Benign + Normal 40 (57.1) & $34(48.6)$ & $6(8.6)$ & $22(31.4)$ & $18(25.7)$ & $27(38.6)$ & $13(18.6)$ & \\
\hline
\end{tabular}

ted mistakenly having malignant masses by the radiologists $\mathrm{R} 1$, $\mathrm{R} 2$ and $\mathrm{R} 3$, respectively.

Summary of radiologist performance for discriminating malignancy is shown in Table 2.

\section{BI-RADS Classification Results}

For R1, R2 and R3, respectively, p values comparing the BI-RADS classification of lesions respect to pathology; diagnostic accuracy (AUC) for CT was $p<0.001, p<0.001$ and $p<0.001$.

For R1, diagnostic accuracy (AUC) was found numerically higher when compared to other radiologists: however, it was not statistically significant.

ROC curve analysis of BI-RADS scores of all lesions by the radiologists were shown in Figure 5.

\section{Interobserver Reliability Results}

Interobserver agreement analyses ICC results are shown on Table 3.

\begin{tabular}{|l|c|}
\hline \multicolumn{2}{|l|}{ Table 3. Interobserver reliability among all radiologist } \\
\hline Parameters & Cl \\
\hline Mass detection & $0.75(0.63-0.84)^{*}$ \\
\hline Lesion Visibility & $0.83(0.73-0.88)^{*}$ \\
\hline Suspect of malignancy & $0.82(0.68-0.87)^{*}$ \\
\hline BI-RADS classification & $0.81(0.72-0.88)^{*}$ \\
\hline $\begin{array}{l}\text { Cl: Confidence intervals. } \\
\text { In this study, an ICC less than 40\% was considered as poor, 40-59\% as fair, 60- } \\
\text { 74\% as good and 75-100\% as excellent"*". } \\
\text { BI-RADS: Breast Imaging Reporting and Data System. }\end{array}$ \\
\hline
\end{tabular}

Interobserver reliability of mass detection, lesion visibility, malignancy suspicion and BI-RADS classification for all radiologists were found within the ranges of 0.75 (95\% Cl 0.63-0.84), 0.83 (95\% Cl 0.73-0.88), 0.82 (95\% Cl 0.68-0.87) and 0.81 (95\% Cl 0.72$0.88)$, respectively.

There were significant interobserver reliability rates between all researchers $(p=0.0001)$. 


\section{DISCUSSION}

In this reader study, high sensitivity and low specificity rates for breast cancer diagnostic accuracy of CT were shown. Interobserver diagnostic capability rates were statistically similar and significant. For breast specific radiologists, even though the diagnostic accuracy of R1 (AUC) was found numerically higher when compared to other radiologists, it was not statistically significant.

Breast cancer is a major health problem worldwide.

While there are many randomized controlled trials of screening mammography to reduce mortality, mammography has many limitations $(22,23)$.

Especially in women with increased risk for breast cancer, dynamic contrast enhanced MRI is much more sensitive than ultrasound and mammography scans $(24,25)$.

Though not considered as a screening method, breast masses are caught incidentally in patients who undergo tomography examination for other reasons. Tomography rates have increased significantly in recent years in clinical practice.

Tomography is a faster, less noisy, comfortable imaging modality and offers more comfortable examination ambience for claustrophobic patients, as well (26).

$\mathrm{C} T$ is a real $3 \mathrm{D}$ high-resolution imaging modality that enhances mass visibility by reducing overlapping of breast tissues and can be considered as an alternative imaging method in patients with MR contraindications, especially in dense breast types.

Our results are comparable to previous studies although they were all prospective incidental study concepts and did not focus on CT diagnostic capability in patients with established diagnosis of cancer.

Hussein et al. have found incidental masses in 33 out of 432 patients. Only 8 of them have been diagnosed with primary cancer. In addition, there is no data regarding the presence of breast mass and no mention of false negative evaluation of the patients (6).

Lin et al. have incidentally detected 23 masses with contrast staining. Sixteen of them have been confirmed as malignant. However, there is no mention of other types of masses such as non-contrast staining. Furthermore, the authors have not given any details related to false negative patients. Therefore, patients with no-contrast staining masses cannot be evaluated in terms of diagnosis (7).

Our study has a different protocol when compared to the previous studies mentioned above. Our study consisted of patients with pathologically confirmed masses and a control group to whom all screening methods were applied and in whom no masses were seen. Therefore, we assume that our study protocol may be more reliable for investigating the role of $\mathrm{CT}$ in discriminating breast masses.

\section{Study Limitations}

Our study had some limitations. First, the study group of the enrolled patients to our study and the number of the radiologists were relatively small. Second, non-mass enhancement lesions, calcifications and focuses were excluded from the research group. Finally, because of the nature of the study, CT examinations were performed independent from the menstrual cycle.

Further studies are required to enrich the findings of the present study.

To the best of our knowledge, our study is the first to evaluate the diagnostic validity of thoracic CT by evaluating the histopathologically confirmed malignant enriched patient population.

\section{CONCLUSION}

Though not considered as a screening method due to adverse effect of radiation, CT may be used in terms of diagnosis of breast cancer with high sensitivity rates.

Our study may reveal that in order to avoid confusion of the normal structures and benign masses as malignant lesions, radiologists should need further training for not only in the appearance of different abnormalities but also in the widely varying appearances of normal tissues leading to positive findings.

Ethics Committee Approval: Ethic committee approval was received for this study from the Institutional local Ethics Committee of Karadeniz Technical University, Medical Faculty (2017/61).

Peer-review: Externally peer-reviewed.

Author Contributions: Consept - H.A.A.K, S.K.; Design - H.A.A.K, S.K.; Supervision - H.A.A.K, S.K.; Resource - H.A.A.K, S.K.; Materials - H.A.A.K, E.B, M.I.Ç.; Data Collection and/or Processing - H.A.A.K, E.B, M.I.Ç.; Analysis and Interpretation - H.A.A.K, E.B, M.I.Ç.; Literature Search - H.A.A.K, M.I.Ç.; Writing Manuscript - H.A.A.K.; Critical Reviews - H.A.A.K, S.K.

Conflict of Interest: The authors have no conflicts of interest to declare.

Financial Disclosure: The authors declared that this study has received no financial support.

\section{REFERENCES}

1. Orel SG, Troupin RH. Nonmammographic imaging of the breast: current issues and future prospects. Semin Roentgenol 1993;231-41. [CrossRef]

2. Monzawa S, Washio T, Yasuoka R, Mitsuo M, Kadotani Y, Hanioka K. Incidental detection of clinically unexpected breast lesions by computed tomography. Acta Radiol 2013;54:374-9. [CrossRef]

3. Broder J, Warshauer DM. Increasing utilization of computed tomography in the adult emergency department, 2000-2005. Emerg Radiol 2006;13:25-30. [CrossRef]

4. Xia JQ, Lo JY, Yang K, Floyd CE, Boone JM. Dedicated breast computed tomography: Volume image denoising via a partial-diffusion equation based technique. Med Phys 2008;35:1950-8. [CrossRef] 
5. Taira N, Ohsumi S, Takabatake D, Hara F, Takashima S, Aogi K, et al. Contrast-enhanced ct evaluation of clinically and mammographically occult multiple breast tumors in women with unilateral early breast cancer. Jpn J Clin Oncol 2008;38:419-25. [CrossRef]

6. Hussain A, Gordon-Dixon A, Almusawy H, Sinha P, Desai A. The incidence and outcome of incidental breast lesions detected by computed tomography. Ann R Coll Surg Engl 2010;92:124-6. [CrossRef]

7. Lin WC, Hsu HH, Li CS, Yu JC, Hsu GC, Yu CP, et al. Incidentally detected enhancing breast lesions on chest computed tomography. Korean J Radiol 2011;12:44-51. [CrossRef]

8. Poyraz N, Emlik GD, Keskin S, Kalkan H. Incidental breast lesions detected on computed thorax tomography. J Breast Health 2015;11:163-7. [CrossRef]

9. Harish MG, Konda SD, MacMahon H, Newstead GM. Breast lesions incidentally detected with CT: what the general radiologist needs to know. Radiographics 2007;27(Supp/ 1):S37-S51. [CrossRef]

10. Moyle P, Sonoda L, Britton P, Sinnatamby R. Incidental breast lesions detected on CT: What is their significance? Br J Radiol 2010;83:233-40. [CrossRef]

11. Son JH, Jung HK, Song JW, Baek HJ, Doo KW, Kim W, et al. Incidentally detected breast lesions on chest ct with us correlation: a pictorial essay. Diagn Interv Radiol 2016;22:514-8. [CrossRef]

12. Krug KB, Houbois C, Grinstein O, Borggrefe J, Puesken M, Hanstein B, et al. Focal breast lesions in clinical CT examinations of the chest: $A$ retrospective analysis. Rofo 2017;189:977-89. [CrossRef]

13. Shojaku H, Seto H, Iwai H, Kitazawa S, Fukushima W, Saito K. Detection of incidental breast tumors by noncontrast spiral computed tomography of the chest. Radiat Med 2008;26:362-7. [CrossRef]

14. Yi JG, Kim SJ, Marom EM, Park JH, Jung SI, Lee MW. Chest CT of incidental breast lesions. J Thorac Imaging 2008;23:148-55. [CrossRef]

15. Meller MT, Cox JE, Callanan KW. Incidental detection of breast lesions with computed tomography. Clin Breast Cancer 2007;7:634-7. [CrossRef]

16. Inoue $M$, Sano $T$, Watai $R$, Ashikaga R, Ueda $K$, Watatani $M$, et al. Dynamic multidetector CT of breast tumors: Diagnostic features and comparison with conventional techniques. AJR Am J Roentgenol 2003;181:679-86. [CrossRef]
17. Porter G, Steel J, Paisley K, Watkins R, Holgate C. Incidental breast masses detected by computed tomography: Are any imaging features predictive of malignancy? Clin Radiol 2009;64:529-33. [CrossRef]

18. Wallis M, Tarvidon A, Helbich T, Schreer I; European Society of Breast Imaging. Guidelines from the European Society of Breast Imaging for diagnostic interventional breast procedures. Eur Radiol 2007;17:581-8. [CrossRef]

19. Spak DA, Plaxco JS, Santiago L, Dryden MJ, Dogan BE. BI-RADS ${ }^{\circledast}$ fifth edition: A summary of changes. Diagn Interv Imaging 2017;98:17990. [CrossRef]

20. Shrout PE, Fleiss JL. Intraclass correlations: uses in assessing rater reliability. Psychol Bull 1979;86:420-8. [CrossRef]

21. IBM Corp. Released 2013. IBM SPSS Statistics for Windows, Version 22.0., Armonk, NY.

22. Marmot M; Independent UK Panel on Breast Cancer Screening, Altman G, Cameron DA, Dewar JA, Thompson SG, et al. Independent UK Panel on Breast Cancer Screening replies to Michael Baum. BMJ 2013;346:f873. [CrossRef]

23. Tabár L, Vitak B, Chen TH, Yen AM, Cohen A, Tot T, et al. Swedish two-county trial: Impact of mammographic screening on breast cancer mortality during 3 decades. Radiology 2011;260:658-63. [CrossRef]

24. Kuhl C, Weigel S, Schrading S, Arand B, Bieling H, König R, et al. Prospective multicenter cohort study to refine management recommendations for women at elevated familial risk of breast cancer: the EVA trial. J Clin Oncol 2010;28:1450-7. [CrossRef]

25. Berg WA, Zhang Z, Lehrer D, Jong RA, Pisano ED, Barr RG, et al. Detection of breast cancer with addition of annual screening ultrasound or a single screening MRI to mammography in women with elevated breast cancer risk. JAMA 2012;307:1394-404. [CrossRef]

26. Kanda T, Nakai Y, Oba H, Toyoda K, Kitajima K, Furui S. Gadolinium deposition in the brain. Magn Reson Imaging 2016;34:1346-50. [CrossRef] 


\section{ORIJINAL ÇALIŞMA-ÖZET}

Turk J Surg 2019; 35 (4): 265-272

\section{Meme kütlelerinin saptanmasında ve iyi-kötü huylu ayrımında tomografinin yeri}

Hatice Ayça Ata Korkmaz ${ }^{1}$, Miraç İsmet Çakır ${ }^{1}$, Eser Bulut ${ }^{1}$, Sibel Kul ${ }^{2}$

${ }^{1}$ Sağlık Bilimleri Üniversitesi, Kanuni Eğitim ve Araşıırma Hastanesi, Radyoloji Kliniği, Trabzon, Türkiye

${ }^{2}$ Karadeniz Teknik Üniversitesi Tıp Fakültesi, Radyoloji Anabilim Dalı, Trabzon, Türkiye

\section{OZZET}

Giriş ve Amaç: Bu çalışmanın temel amacı bilgisayarlı tomografi (BT)'nin meme kütlelerini saptamadaki yerini ve lezyonların iyi ya da kötü huylu ayrımını yapabilirliğini değerlendirmektir.

Gereç ve Yöntem: Etik kurul onayı sonrası, alanında tecrübeli ve çalışmaya araştırmacı olarak katılmayacak bir radyolog tarafından $2010-2018$ yılları arasında, hastanemizin Patoloji Bölümü veritabanı taranarak bir hasta havuzu oluşturulmuştur. Oluşturulan hasta havuzunda yoğun ve yoğun olmayan meme tiplerinin, iyi ve kötü huylu lezyon sayılarının ve lezyon boyutlarının eşit oranlarda olmasına özen gösterilmiştir. Sonuç olarak her meme tipinde eşit oranda olmak üzere kötü huylu tümör tanısı almış 30, iyi huylu tümör tanısı almış 20 ve taramalarda herhangi bir meme lezyonu bulunmayan 20 kontrol grubu hasta olmak üzere toplamda 70 hasta çalışmaya dahil edilmiştir. Meme Radyolojisi konusunda deneyimli üç radyolog (R1, R2, R3) tarafından tüm BT görüntüleri nihai tanıya kör olarak ayrı ayrı değerlendirilmiştir. Okuyucu performansları, eğri altındaki alanın (AUC) hesaplanmasıyla değerlendirilmiş ve araştırmacılar arası güvenilirlik, sınıf içi korelasyon katsayısı (ICC) analizi ile hesaplanmıştır.

Bulgular: R1, R2 ve R3 için sırasıyla BT'nin BI-RADS skorlama sistemine göre doğru tanı koyma yeterliliği; $p<0.001, p<0.001$ ve $p<0.001$ olarak belirlenmiş̧ir. Araştırmacıların tümü arasında anlamlı bir okuyucu güvenilirliği saptanmıştır ( $p=0.0001)$.

Sonuç: BT, meme kütlelerinin saptanmasında ve iyi-kötü huylu ayrımının yapılmasında, yalancı pozitifliğe yol açabilecek normal meme dokularının BT görüntüleri hakkında ileri eğitim alınması halinde oldukça faydalı bir görüntüleme yöntemi olarak kullanılabilir.

Anahtar Kelimeler: Bilgisayarlı tomografi, toraks, meme kanseri, meme tomografisi

Doi: $10.5578 /$ turkjsurg. 4258 